\title{
Manipulation of progesterone to increase ovulatory response to the first GnRH treatment of an Ovsynch protocol in lactating dairy cows receiving first timed artificial insemination
}

P. D. Carvalho, M. C. Wiltbank, and P. M. Fricke ${ }^{1}$

Department of Dairy Science, University of Wisconsin, Madison 53706

\section{ABSTRACT}

Ovulation to the first GnRH (G1) treatment of the Ovsynch protocol improves synchronization rate and pregnancies per AI (P/AI). Elevated progesterone (P4) concentrations at G1 decrease the ovulatory response by decreasing the magnitude of the $\mathrm{GnRH}$-induced $\mathrm{LH}$ surge. Therefore, our objective was to evaluate the effect of temporarily decreasing $\mathrm{P} 4$ concentrations before initiation of an Ovsynch protocol on ovulatory response to G1 and P/AI. Lactating Holstein cows $(\mathrm{n}=800)$ at $53 \pm 3$ (herd A) or $51 \pm 3$ (herd B) d in milk (DIM) were synchronized using a modified Double-Ovsynch protocol [pre-Ovsynch protocol (d 0, GnRH; d 7, $\mathrm{PGF}_{2 \alpha} ; \mathrm{d} 10$, $\mathrm{GnRH}$ ) followed $7 \mathrm{~d}$ later by an Ovsynch-56 protocol (d $\left.\left.0, \mathrm{G} 1 ; \mathrm{d} 7, \mathrm{PGF}_{2 \alpha} ; \mathrm{d} 8, \mathrm{PGF}_{2 \alpha} ; \mathrm{d} 9.5, \mathrm{GnRH}\right)\right]$ to receive first timed artificial insemination (TAI; $80 \pm 3$ DIM) 16 $\mathrm{h}$ after the last GnRH treatment. Cows were randomly assigned to receive $12.5 \mathrm{mg}$ of $\mathrm{PGF}_{2 \alpha}$ (a half-dose of dinoprost tromethamine) 2 d before G1 (low-P4) or serve as untreated controls (high-P4). Overall, high-P4 cows had greater P4 concentrations at G1 compared with low-P4 cows (3.0 vs. $1.3 \mathrm{ng} / \mathrm{mL}$, respectively). Ovulatory response to G1 was greater for low-P4 than high-P4 cows [81.1 vs. $60.3 \%$, respectively]. Premature luteal regression during the second Ovsynch protocol did not differ between treatments $[15.0 \%$ vs. $10.7 \%$; for low-P4 vs. high-P4 cows, respectively]. Overall, P/ AI did not differ between treatments $32 \mathrm{~d}$ after TAI $[56.3$ vs. $52.9 \%$, for low-P 4 vs. high-P 4 cows, respectively] or $67 \mathrm{~d}$ after AI [50.5 vs. $47.6 \%$, for low-P4 vs. high-P 4 cows, respectively]. Pregnancy loss from 32 to $67 \mathrm{~d}$ after TAI did not differ between treatments [9.9 vs. $9.3 \%$, for low-P4 vs. high-P4 cows, respectively]. Overall, cows that ovulated to G1 had more P/AI than cows that did not ovulate [58.2 vs. $41.8 \%$, respectively]. The increase in $\mathrm{P} / \mathrm{AI}$ for cows that ovulated to G1

Received June 15, 2015.

Accepted August 24, 2015.

${ }^{1}$ Corresponding author: pmfricke@wisc.edu
(16.4\%) combined with the observed increase in ovulation to G1 due to treatment (20.8\%; low-P4 - high-P4) resulted in the expected numerical increase in $\mathrm{P} / \mathrm{AI}$ of $3.4 \%$ in low-P4 versus high-P4 cows observed in this experiment. We conclude that administration of a halfdose of $\mathrm{PGF}_{2 \alpha} 2 \mathrm{~d}$ before G1 during a Double-Ovsynch protocol decreased P4 at G1 and increased ovulatory response to G1.

Key words: progesterone, timed artificial insemination, fertility

\section{INTRODUCTION}

The use of hormonal synchronization programs to submit cows for first timed AI (TAI) has increased AI service rates, thereby resulting in more cows inseminated after the end of the voluntary waiting period and increasing the proportion of pregnant cows during early lactation (Pursley et al., 1997; Fricke et al., 2014; Wiltbank and Pursley, 2014). Compared with initiation of the Ovsynch protocol at random stages of the estrous cycle, the use of hormonal treatments that presynchronize the estrous cycle so that an Ovsynch protocol is initiated during early diestrous (d 5 to 9 ) increases pregnancies per AI (P/AI; Moreira et al., 2001; Navanukraw et al., 2004) by increasing overall response to each treatment of the Ovsynch protocol (Vasconcelos et al., 1999; Bello et al., 2006). Furthermore, presynchronization of the estrous cycle with an Ovsynch protocol (i.e., Double-Ovsynch) tightly controls the day of the cycle in which the Ovsynch protocol is initiated, increases the response to each hormonal treatment (Ayres et al., 2013), and optimizes progesterone (P4) concentrations during the Ovsynch protocol which in turn increases P/AI (Souza et al., 2008; Herlihy et al., 2012; Carvalho et al., 2014a).

Of particular importance to the present study, compared with cows failing to ovulate to the first $\mathrm{GnRH}$ (G1) treatment of the Ovsynch protocol, cows that ovulate to G1 have improved responses to the remaining treatments during the protocol (Vasconcelos et al., 1999; Bello et al., 2006) and more P/AI (Chebel et al., 
2006; Galvão et al., 2007; Giordano et al., 2013). When $\mathrm{P} 4$ concentrations are high $(>3 \mathrm{ng} / \mathrm{mL})$, however, the ovulatory response to G1 is decreased because of a negative effect of $\mathrm{P} 4$ on the GnRH-induced $\mathrm{LH}$ surge (Giordano et al., 2012a). In this regard, increasing the dose of GnRH at G1 from 100 to $200 \mu \mathrm{g}$ increased the magnitude of the GnRH-induced LH surge (Giordano et al., 2012a) and increased ovulatory response from 58 to $67 \%$ (Giordano et al., 2013). Another possible strategy to overcome the negative effect of $\mathrm{P} 4$ on the GnRH-induced LH surge would be to decrease P4 concentrations at G1. In fact, the GnRH-induced LH surge and ovulatory response to a $\mathrm{GnRH}$ treatment are greater for cows with low P4 compared with cows with high $\mathrm{P} 4$ concentrations at the time of treatment with GnRH (Giordano et al., 2012a; Ayres et al., 2013). Recently, Nascimento et al. (2014) demonstrated that treatment with $\mathrm{PGF}_{2 \alpha}$ on $\mathrm{d} 5$ of the estrous cycle did not induce complete luteolysis but resulted in a temporary decrease in $\mathrm{P} 4$ concentrations for $\sim 2 \mathrm{~d}$ followed by a resurgence of $\mathrm{P} 4$ concentrations and maintenance of the corpus luteum $(\mathbf{C L})$. Thus, treatment with $\mathrm{PGF}_{2 \alpha}$ on $\mathrm{d} 5$ could result in reduced $\mathrm{P} 4$, increased responsiveness to GnRH, and an increased ovulatory response to G1.

Therefore, our objective was to evaluate the effect of temporarily decreasing $\mathrm{P} 4$ concentrations at G1 by administering a half-dose of $\mathrm{PGF}_{2 \alpha}$ (12.5 mg of dinoprost tromethamine) $2 \mathrm{~d}$ before initiation of the Ovsynch protocol on ovulatory response to G1, P4 concentrations, and P/AI. Our hypotheses were that administration of a half-dose of $\mathrm{PGF}_{2 \alpha} 2 \mathrm{~d}$ before G1 would decrease P4 concentrations at G1, without causing complete luteolysis, and increase ovulatory response to G1. We further hypothesized that cows ovulating to G1 would have more $\mathrm{P} / \mathrm{AI}$ compared with cows failing to ovulate, and that the increase in $\mathrm{P} / \mathrm{AI}$ for cows treated with a half-dose of $\mathrm{PGF}_{2 \alpha}$ would be dependent on the increase in the proportion of cows ovulating to G1.

\section{MATERIALS AND METHODS}

All animal handling and experimental procedures were approved by the Animal Care and Use Committee of the College of Agriculture and Life Sciences at the University of Wisconsin-Madison.

\section{Cows, Housing, and Feeding}

This study was conducted from January 2014 to December 2014 in a research herd and a commercial dairy herd (herds A and B, respectively) in Wisconsin. Lactating Holstein cows were milked twice daily at ap- proximately 12 -h intervals in herd $\mathrm{A}$ and thrice daily at 8-h intervals in herd B. In both locations, cows were fed once daily a TMR consisting of corn and alfalfa silage as forage with corn and soybean meal-based concentrate formulated to meet or exceed the minimum nutritional requirements for high-producing dairy cows (NRC, 2001). Cows were housed in freestall barns bedded with sand and had ad libitum access to feed and water. Primiparous cows were housed in separate pens from multiparous cows. In herd A, barns were equipped with fans, but not sprinklers, that were automatically activated when the temperature inside the barns exceeded $20^{\circ} \mathrm{C}$. In herd $\mathrm{B}$, barns were equipped with fans and sprinklers that were automatically activated when the temperature inside the barns exceeded $20^{\circ} \mathrm{C}$. As per the management procedures in place in herd $\mathrm{A}$, multiparous cows received somatotropin $(500 \mathrm{mg} /$ dose; Posilac, Elanco, Greenfield, IN) every $14 \mathrm{~d}$ starting at $67 \pm 3 \mathrm{~d}$ postpartum, whereas somatotropin was not administered to primiparous cows. In herd B, somatotropin was administered to all cows every $14 \mathrm{~d}$ starting at $67 \pm 3 \mathrm{~d}$ postpartum. The rolling herd average in herd A was $13,744 \mathrm{~kg}$, and average daily milk production was $41.6 \mathrm{~kg} / \mathrm{cow}$ with $3.8 \%$ fat and $3.2 \%$ protein, whereas in herd B the rolling herd average was 14,933 $\mathrm{kg}$ and average daily milk production was $46.3 \mathrm{~kg} / \mathrm{cow}$ with $3.7 \%$ fat and $3.1 \%$ protein for the entire herd during the period of this experiment.

\section{Treatments and Al}

Cows had their estrous cycles synchronized for first TAI using a Double-Ovsynch protocol starting at 53 \pm 3 DIM in herd A and $51 \pm 3$ DIM in herd B, as described by Souza et al. (2008) and later modified by Brusveen et al. (2009). The GnRH (100 $\mu \mathrm{g} /$ dose of gonadorelin hydrochloride, Factrel) and the $\mathrm{PGF}_{2 \alpha}(25$ $\mathrm{mg}$ /dose of dinoprost tromethamine, Lutalyse) were from Zoetis (Madison, NJ). Briefly, cows received the first GnRH treatment of the Presynch portion of the Double-Ovsynch, followed by a treatment with $\mathrm{PGF}_{2 \alpha}$ $7 \mathrm{~d}$ later and $\mathrm{GnRH} 72 \mathrm{~h}$ after $\mathrm{PGF}_{2 \alpha}$. Seven days later, cows received a $\mathrm{GnRH}$ (G1) treatment followed by $2 \mathrm{PGF}_{2 \alpha}$ treatments administered 7 and $8 \mathrm{~d}$ later, with the last $\mathrm{GnRH}(\mathrm{G} 2)$ treatment administered 56 $\mathrm{h}$ after the first $\mathrm{PGF}_{2 \alpha}$ treatment and AI 16 to $20 \mathrm{~h}$ later (Figure 1). Within each herd, cows $(\mathrm{n}=800 ; \mathrm{n}$ $=560$ herd $\mathrm{A} ; \mathrm{n}=240$ herd $\mathrm{B}$ ) were blocked by parity (primiparous vs. multiparous) and randomly assigned to serve as untreated controls (high-P4) or to receive a half dose of $\mathrm{PGF}_{2 \alpha}$ (low-P4; $12.5 \mathrm{mg}$ of dinoprost tromethamine) $2 \mathrm{~d}$ before G1 (Figure 1). At each location, multiple sires with high genetic merit and proven 


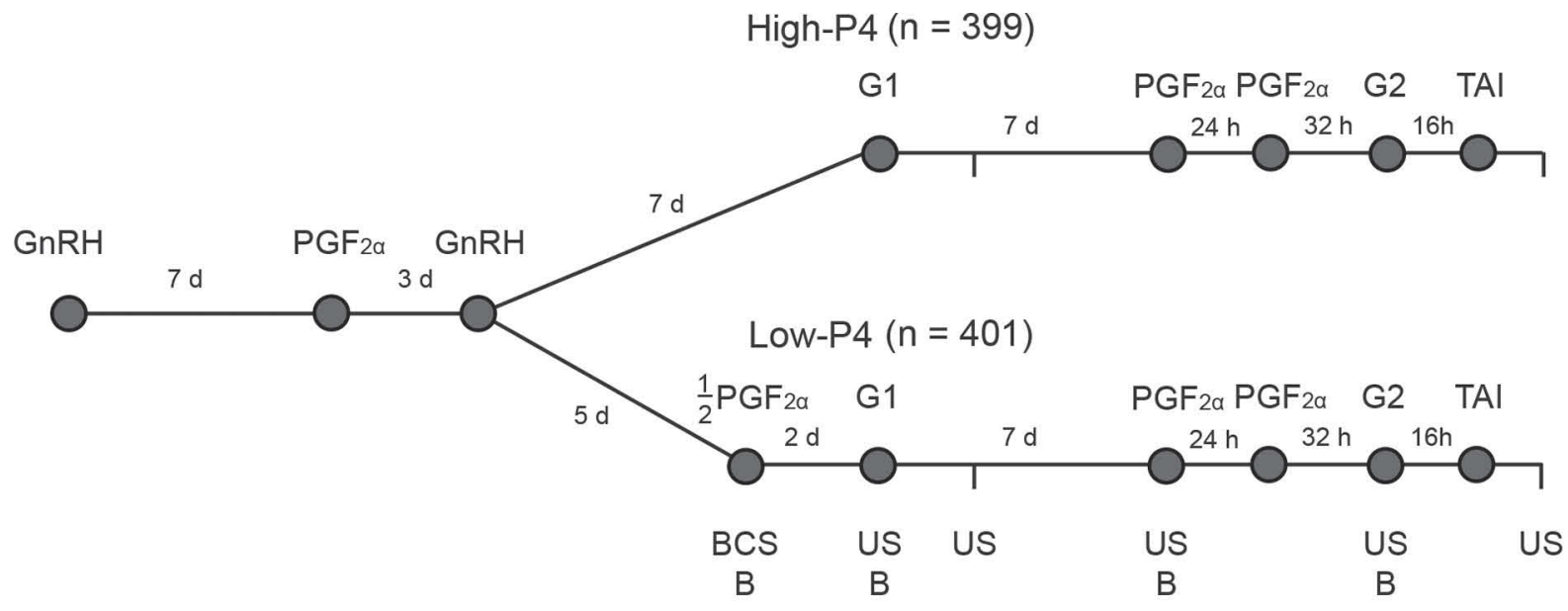

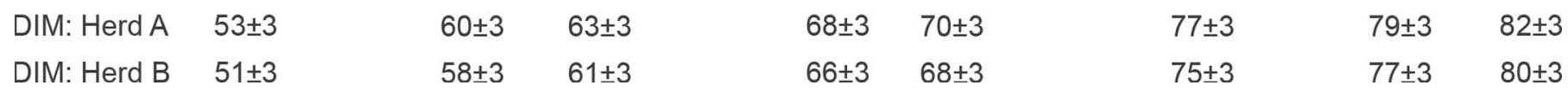

Figure 1. Schematic representation of treatments. Cows had their estrous cycles synchronized using a Double-Ovsynch protocol. The first $\mathrm{GnRH}$ treatment of the Presynch portion of the Double-Ovsynch was followed by treatment with $\mathrm{PGF}_{2 \alpha} 7 \mathrm{~d}$ later and $\mathrm{GnRH} 72 \mathrm{~h}$ after PGF $\mathrm{P}_{2 \alpha}$. Seven days later, cows received a $\mathrm{GnRH}(\mathrm{G} 1)$ treatment followed $2 \mathrm{PGF}_{2 \alpha}$ treatments administered 7 and $8 \mathrm{~d}$ later with the last GnRH (G2) treatment administered $56 \mathrm{~h}$ after the first $\mathrm{PGF}_{2 \alpha}$ treatment and $\mathrm{AI} 16$ to $20 \mathrm{~h}$ later. Two days before G1 cows were blocked by parity (primiparous vs. multiparous) and were randomly assigned to serve as untreated controls (high-P4) or to receive a half dose of $\mathrm{PGF}_{2 \alpha}$ (low-P4; 12.5 mg dinoprost tromethamine). $\mathrm{P} 4=$ progesterone; $\mathrm{B}=$ blood sample; US = ovarian ultrasonography; TAI = timed AI.

fertility were used and were equally balanced between treatments.

\section{Ultrasound Evaluation of the Ovaries}

Ovarian structures at G1, $56 \mathrm{~h}$ after G1, at the time of the first $\mathrm{PGF}_{2 \alpha}$ treatment, at $\mathrm{G} 2$, and $56 \mathrm{~h}$ after $\mathrm{G} 2$ were recorded for a subgroup of cows (high-P4, $\mathrm{n}=$ 116; low-P4, n = 116; Figure 1) by transrectal ultrasonography using a portable scanner (Ibex Pro, E. I. Medical Imaging, Loveland, CO) equipped with a 7.5$\mathrm{MHz}$ linear-array transducer. Images were frozen when the ovarian structures were determined visually to be at their maximal size. Structure size was determined by taking the average of 2 perpendicular measurements [length (L) and width (W)] obtained using the built-in calipers of the ultrasound machine. All structures were mapped and recorded. Ovulation was defined based on disappearance of one or more ovulatory-sized follicles $(\geq 10$ in diameter; Sartori et al., 2001) by $56 \mathrm{~h}$ after each GnRH (G1 and G2) treatment. Regression of CL during the Ovsynch protocol was based on disappearance of at least one CL that was present at the time of G1 and disappearance of that structure by the time of the first $\mathrm{PGF}_{2 \alpha}$ treatment. Total CL volume was determined by the formula $\mathrm{V}=4 / 3 \times \pi \times \mathrm{R}^{3}$, using a radius $(\mathrm{R})$ obtained with the formula $\mathrm{R}=(\mathrm{L} / 2+$ $\mathrm{W} / 2) / 2$. When a cavity was present, the volume of the cavity was calculated and subtracted from the total CL volume.

\section{Blood Sampling and Progesterone Assay}

Blood samples from a subgroup of cows were collected via puncture of the median caudal vein or artery into 8-mL evacuated serum collection tubes (Vacuette, Greiner Bio-One North America Inc., Monroe, NC). Samples were collected immediately before administration of treatments at (1) day of treatment ( $2 \mathrm{~d}$ before G1: high-P4, $\mathrm{n}=139$; low-P4, $\mathrm{n}=138$ ); (2) G1 (high$\mathrm{P} 4, \mathrm{n}=144$; low-P4, $\mathrm{n}=145$ ); (3) first $\mathrm{PGF}_{2 \alpha}$ (high-P4, $\mathrm{n}=138$; low-P4, $\mathrm{n}=139$ ); and (4) G2 (high-P4, $\mathrm{n}=$ 136 ; low-P4, $\mathrm{n}=135$ ) of the Ovsynch-56 protocol (Figure 1). After collection, blood samples were refrigerated for $24 \mathrm{~h}$ and centrifuged $\left(1,600 \times g ; 4^{\circ} \mathrm{C}\right)$ for $20 \mathrm{~min}$. Serum was harvested and stored at $-20^{\circ} \mathrm{C}$ until assayed for $\mathrm{P} 4$ concentration using a solid-phase, no-extraction radioimmunoassay (Coat-a-Count; Diagnostic Products Corporation, Los Angeles, CA). The average sensitivity for the 3 assays was $0.027 \mathrm{ng} / \mathrm{mL}$. The average intraassay CV was $5.61 \%$, and the interassay CV was $6.91 \%$ based on a quality control sample $(2.50 \mathrm{ng} / \mathrm{mL}$ of P4), which was replicated within each assay.

\section{Pregnancy Diagnosis}

In both herds, pregnancy diagnosis was performed $32 \mathrm{~d}$ after TAI for all cows in both treatments using a portable scanner (Ibex Pro, E. I. Medical Imaging) equipped with a $7.5-\mathrm{MHz}$ linear-array transducer. A positive pregnancy diagnosis was based on visualiza- 
tion of a CL on the ovary ipsilateral to the uterine horn containing an embryo with a heartbeat. Pregnancy status for cows diagnosed pregnant was reconfirmed at 46 and $67 \mathrm{~d}$ after TAI using the same ultrasound machine. Twin pregnancy diagnosis was performed on the day of the third pregnancy diagnosis at $67 \mathrm{~d}$ after AI. Cows diagnosed pregnant and then diagnosed not pregnant at the subsequent pregnancy examination were considered to have undergone pregnancy loss.

\section{BCS Evaluation and Milk Yield}

Body condition score was evaluated at enrollment $(68 \pm 3$ DIM on herd A and at $66 \pm 3$ DIM on herd B) using a 5 -point scale with 0.25 increments where $1=$ thin and $5=$ fat (Edmonson et al., 1989). The same individual performed all BCS evaluations throughout the experiment. Based on previous research (Carvalho et al., 2014b), BCS was categorized as either low $(\leq 2.50)$ or high ( $\geq 2.75)$ for statistical analysis.

Milk weights were recorded once monthly and stored in the on-farm computer software program (Dairy Comp 305; Valley Agricultural Software, Tulare, CA). For statistical analysis, average milk weights of the first 3 tests were used and cows were categorized by parity (primiparous vs. multiparous), according to milk production, as being below or above mean milk production.

\section{Statistical Analyses}

The experimental design was a complete randomized block design with parity (primiparous vs. multiparous) as the blocking factor. All statistical analyses were performed using SAS computational software, version 9.4 for Microsoft Windows (SAS Institute Inc., Cary, NC).

Analysis of binary response data (P/AI, pregnancy loss, twins, ovulatory response at G1 and G2, double ovulation at G2, the proportion of cows with a follicle $\geq 10 \mathrm{~mm}$ at G1, the proportion of cows with a CL at $\mathrm{G} 1$ and $\mathrm{PGF}_{2 \alpha}$, and the proportion of cows regressing at least one CL from G1 to the $\mathrm{PGF}_{2 \alpha}$ treatment) was performed by logistic regression using the GLIMMIX procedure of SAS. Fixed effects included in the initial models were treatment, parity, ovulation at G1 (not included for ovulatory response at G1), BCS category, milk production, as well as the interaction between these variables, whereas cow was included as a random effect. Selection of the fixed effects model that best fit the data for each variable of interest was performed by finding the model with the lowest value for the Akaike information criterion using a backward elimination procedure that removed from the model all variables with a $P$-value exceeding 0.10 . Both treatment and parity were forced to remain in the model. Parity was forced into the final model because it was used as a blocking factor for randomization of cows to treatments. Statistical differences between cows ovulating or not ovulating at G1 were analyzed using Fisher's exact test for percentage of cows with a follicle $\geq 10 \mathrm{~mm}$ at G1, percentage of cows with a $\mathrm{CL}$ at $\mathrm{G} 1$ and $\mathrm{PGF}_{2 \alpha}$, and ovulatory response at $\mathrm{G} 2$.

For $\mathrm{P} / \mathrm{AI}$ at 32,46 , and 67 after TAI, the final model contained the fixed effects of treatment, parity, ovulation at G1, and BCS. Because parity was not significant in the logistic regression model, differences in $\mathrm{P} / \mathrm{AI}$ between parities within treatments were obtained using a chi-squared test. The same categorical variables and interactions used for $\mathrm{P} / \mathrm{AI}$ were used to obtain models for analysis of pregnancy loss (from 32 to 46, 46 to 67 , and 32 to $67 \mathrm{~d}$ after TAI) and twin pregnancies. The procedure and criteria used for model selection were similar to those used for P/AI. The final model included the fixed effects of treatment and parity.

Differences in ovulatory response at G1 were determined by logistic regression using the GLIMMIX procedure of SAS. The procedure and criteria used for model selection were similar to those used for P/AI. The final model included the fixed effects of treatment and parity. Furthermore, differences in ovulatory response among P4 categories were determined by logistic regression using the GLIMMIX procedure of SAS. The model included only $\mathrm{P} 4$ as a categorical variable. In addition, differences in ovulatory response among follicle size category were determined by logistic regression using the GLIMMIX procedure of SAS. The model included the effect of $\mathrm{P} 4$ ( $<1.5$ vs. $\geq 1.5 \mathrm{ng} / \mathrm{mL}$ ) at G1 as a categorical variable, as well as the linear and quadratic effect of follicle size, and the interaction between $\mathrm{P} 4$ category ( $<1.5$ vs. $\geq 1.5 \mathrm{ng} / \mathrm{mL})$ and follicle size.

Differences in milk production and BCS were determined by ANOVA using the MIXED procedure of SAS. The model contained as fixed effects treatment, month postpartum (for evaluation of milk production only), parity, and their interaction, whereas cow was used as a random effect in the model. Differences in the proportion of cows with low $(\leq 2.50)$ BCS were determined by logistic regression using the LOGISTIC procedure of SAS. The model contained as fixed effects treatment, parity, and their interaction, whereas cow was used as a random effect in the model.

Data were examined for normality using the ShapiroWilk test. A significant $P$-value indicated that data were not normally distributed; therefore, data were transformed to ranks. For evaluation of circulating P4 profiles from 2 d before G1 to G2, only cows with P4 data at all time points were used. Differences between treatments were determined by ANOVA using the MIXED procedure of SAS and a model containing the 
fixed effect of treatment, time, and their interaction. Due to repeated measures within each cow, a repeated statement was used to account for autocorrelations by modeling the spatial power between sequential measurements. Further analysis of treatment differences in circulating $\mathrm{P} 4$ concentrations at $2 \mathrm{~d}$ before $\mathrm{G} 1$, at G1, at the first $\mathrm{PGF}_{2 \alpha}$, and at the G2 treatment of the Ovsynch-56 protocol, were determined by ANOVA using the MIXED procedure of SAS. The model contained as fixed effects treatment, parity, their interaction, and ovulation at G1, whereas cow was used as a random effect in the model. Cows were distributed into 9 categories using P4 concentration at G1 and the $\mathrm{PGF}_{2 \alpha}$ treatment of the Ovsynch-56 protocol (from 0.0 to $\geq 4.0 \mathrm{ng} / \mathrm{mL}$ in $0.5 \mathrm{ng} / \mathrm{mL}$ increments). At $\mathrm{G} 2$, cows were divided into 5 categories $(0.0$ to $\geq 0.4 \mathrm{ng} / \mathrm{mL}$ in $0.1 \mathrm{ng} / \mathrm{mL}$ increments). Differences in the proportion of cows within each $\mathrm{P} 4$ category were analyzed by logistic regression using the LOGISTIC procedure of SAS.

Differences in luteal volume at G1 and at the first $\mathrm{PGF}_{2 \alpha}$ treatment, follicle diameter at G1 and G2, and number of CL at $\mathrm{G} 1$ and at the first $\mathrm{PGF}_{2 \alpha}$ treatment were determined by ANOVA using the MIXED procedure of SAS. The model contained as fixed effects treatment, parity, their interaction, and ovulation at G1, whereas cow was used as a random effect in the model.

Differences in the distribution of cows based on follicle size at G2 for cows ovulating or not ovulating to G1 was performed using LOGISTIC procedure of SAS. For analysis of the effect of follicle diameter at G2 on $\mathrm{P} / \mathrm{AI}$ for cows ovulating or not ovulating to G1, only cows ovulating to G2 were included in the analysis.

A significant difference between the levels of a classification variable was considered when $P \leq 0.05$, whereas differences between $P>0.05$ and $P \leq 0.10$ were considered a statistical tendency. Data are presented as means \pm SEM, obtained using the MEANS procedure of SAS.

\section{RESULTS}

\section{Milk Production and BCS}

Average milk yield during the first 3 mo after calving did not differ $(P=0.70)$ between treatments (46.5 vs. $46.7 \mathrm{~kg} / \mathrm{d}$, for high-P4 vs. low-P4 cows, respectively); however, milk production was less $(P<0.001)$ for primiparous cows than for multiparous cows (35.8 vs. 51.4 $\mathrm{kg} / \mathrm{d}$, respectively).

On the day of enrollment, BCS did not differ $(P=$ $0.82)$ between treatments (2.79 vs. 2.79 , for high-P 4 vs. low-P4 cows, respectively); however, primiparous cows had a higher $(P<0.001)$ BCS than multiparous cows
(2.95 vs. 2.72 , respectively). The proportion of cows with low $(\leq 2.50)$ BCS did not differ $(P=0.33)$ between treatments $[27.6 \%(110 / 399)$ vs. $29.9 \%(120 / 401)$, for high-P4 vs. low-P4 cows, respectively]. Nevertheless, fewer $(P<0.01)$ primiparous cows had low BCS than multiparous cows $[7.9 \%(19 / 240)$ vs. $37.7 \%(211 / 560)$, respectively].

\section{P/AI, Pregnancy Loss, and Twins}

At $32 \mathrm{~d}$ after TAI, $\mathrm{P} / \mathrm{AI}$ did not differ $(P=0.29)$ between treatments (Table 1$)$ or $(P=0.95)$ between parities $[57.5 \%(138 / 240)$ vs. $53.3 \%(295 / 553)$, for primiparous vs. multiparous cows, respectively]. Furthermore, $\mathrm{P} / \mathrm{AI}$ did not differ $(P=0.60)$ between treatments for primiparous $[55.8 \%(67 / 120)$ vs. $59.2 \%$ $(71 / 120)$, for high-P4 vs. low-P4, respectively] or $(P$ $=0.42)$ multiparous cows $[51.6 \%(142 / 275)$ vs. $55.0 \%$ (153/278), for high-P4 vs. low-P4, respectively]. Cows with low $(\leq 2.50)$ BCS had fewer $(P<0.01) \mathrm{P} / \mathrm{AI}$ than cows with high $(\geq 2.75)$ BCS $[45.1 \%(102 / 226)$ vs. $58.4 \%(331 / 567)$, respectively].

At $46 \mathrm{~d}$ after TAI, P/AI did not differ $(P=0.27)$ between treatments (Table 1). Overall, P/AI $46 \mathrm{~d}$ after TAI did not differ $(P=0.99)$ between primiparous and multiparous cows $[54.6 \%(131 / 240)$ vs. $50.7 \%$ $(279 / 550)$, respectively]. Nevertheless, cows with low $(\leq 2.50)$ BCS had fewer $(P<0.01) \mathrm{P} / \mathrm{AI}$ than cows with high $(\geq 2.75)$ BCS $[42.4 \%(95 / 224)$ vs. $55.7 \%$ $(315 / 566)$, respectively].

At $67 \mathrm{~d}$ after TAI, P/AI did not differ $(P=0.33)$ between treatments (Table 1$)$ or $(P=0.95)$ parities $[52.1 \%(125 / 240)$ vs. $50.7 \%(261 / 547)$, for primiparous versus multiparous cows, respectively]; however, cows with low $(\leq 2.50)$ BCS had fewer $(P<0.01) \mathrm{P} / \mathrm{AI}$ than cows with high $(\geq 2.75)$ BCS $[37.8 \%(84 / 222)$ vs. $53.5 \%$ $(302 / 565)$, respectively].

Overall pregnancy loss for all cows from 32 to $46 \mathrm{~d}$ and from 46 to $67 \mathrm{~d}$, and total pregnancy loss from 32 to $67 \mathrm{~d}$ after TAI was $4.7,5.2$, and $9.6 \%$, respectively. Pregnancy loss from 32 to $46 \mathrm{~d}$ after TAI did not differ $(P=0.87)$ between treatments (Table 1$)$, parities $[P=$ $0.72,5.1 \%(7 / 138)$ vs. $4.5 \%$ (13/292), for primiparous vs. multiparous cows, respectively], or BCS categories $[P=0.77,5.0 \%(5 / 100)$ vs. $4.5 \%(15 / 330)$, for cows with low $(\leq 2.50)$ vs. high $(\geq 2.75)$ BCS, respectively]. Similarly, pregnancy loss from 46 to $67 \mathrm{~d}$ after TAI did not differ $(P=0.62)$ between treatments (Table 1$)$ or parities $[P=0.72,4.6 \%(6 / 131)$ vs. $5.4 \%(15 / 276)$ for primiparous vs. multiparous cows, respectively]; however, cows with low $(\leq 2.50)$ BCS had more $(P=$ $0.03)$ pregnancy loss than cows with high $(\geq 2.75)$ BCS [9.7\% (9/93) vs. $3.8 \%(12 / 314)$, respectively]. Overall pregnancy loss from 32 to $67 \mathrm{~d}$ after TAI did not differ 
Table 1. Effect of treatment on pregnancies per artificial insemination (P/AI) after first timed AI and pregnancy loss in lactating Holstein cows

\begin{tabular}{|c|c|c|c|}
\hline \multirow[b]{2}{*}{ Item } & \multicolumn{2}{|c|}{ Treatment $^{1}$} & \multirow[b]{2}{*}{$P$-value } \\
\hline & High P4 & Low $\mathrm{P} 4$ & \\
\hline \multicolumn{4}{|c|}{$\overline{\mathrm{P} / \mathrm{AI}, \% \text { (no./no.) }}$} \\
\hline $32 \mathrm{~d}$ & $52.9(209 / 395)$ & $56.3(224 / 398)$ & 0.29 \\
\hline $46 \mathrm{~d}$ & $50.1(197 / 393)$ & $53.7(213 / 397)$ & 0.27 \\
\hline $67 \mathrm{~d}$ & $47.6(186 / 391)$ & $50.5(200 / 396)$ & 0.33 \\
\hline \multicolumn{4}{|c|}{ Pregnancy loss, \% (no./no.) } \\
\hline 32 to $46 \mathrm{~d}$ & $4.8(10 / 207)$ & $4.5(10 / 223)$ & 0.87 \\
\hline 46 to $67 \mathrm{~d}$ & $4.6(9 / 195)$ & $5.7(12 / 212)$ & 0.62 \\
\hline 32 to $67 \mathrm{~d}$ & $9.3(19 / 205)$ & $9.9(22 / 222)$ & 0.81 \\
\hline
\end{tabular}

${ }^{1}$ Cows had their estrous cycles synchronized for first timed AI using a Double-Ovsynch protocol. The first GnRH treatment of the Presynch portion of the Double-Ovsynch protocol was followed by treatment with $\mathrm{PGF}_{2 \alpha} 7 \mathrm{~d}$ later and $\mathrm{GnRH} 72 \mathrm{~h}$ after $\mathrm{PGF}_{2 \alpha}$. Seven days later, cows received a GnRH (G1) treatment followed by $2 \mathrm{PGF}_{2 \alpha}$ treatments administered 7 and $8 \mathrm{~d}$ later with the last $\mathrm{GnRH}$ (G2) treatment administered $56 \mathrm{~h}$ after the first $\mathrm{PGF}_{2 \alpha}$ treatment and timed AI 16 to $20 \mathrm{~h}$ later. Two days before G1, cows were blocked by parity (primiparous vs. multiparous) and were randomly assigned to serve as untreated controls (high progesterone, $\mathrm{P} 4)$ or to receive a half dose of $\mathrm{PGF}_{2 \alpha}$ (low $\mathrm{P} 4 ; 12.5 \mathrm{mg}$ of dinoprost tromethamine).

$(P=0.81)$ between treatments (Table 1$)$ or parities $[P=0.61,9.4 \%(13 / 138)$ vs. $9.7 \%(28 / 289)$, for primiparous vs. multiparous cows, respectively]; however, cows with low $(\leq 2.50)$ BCS tended to have more $(P=$ $0.07)$ pregnancy loss than cows with high $(\geq 2.75)$ BCS [14.3\% (14/98) vs. $8.2 \%(27 / 329)$, respectively].

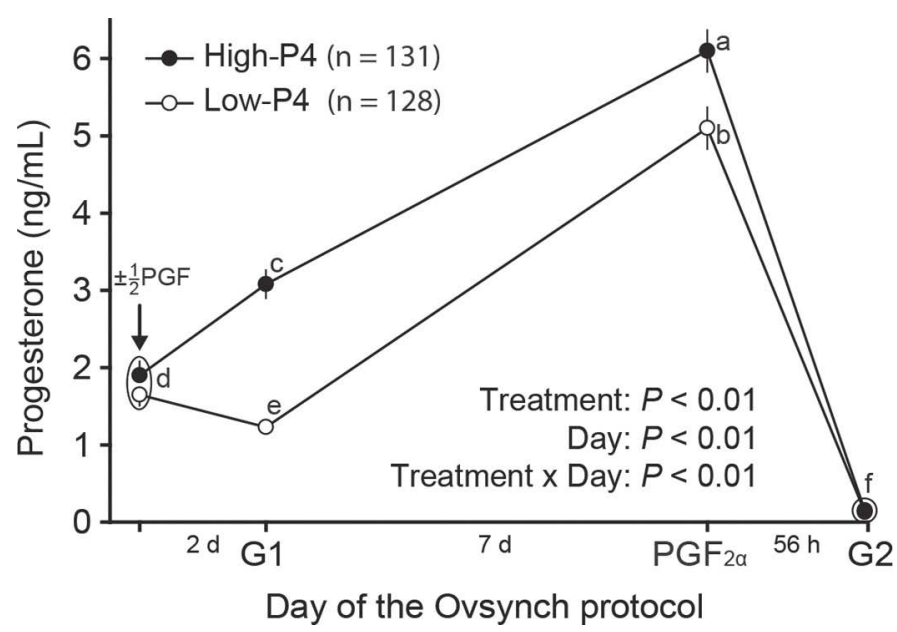

Figure 2. Concentrations $(\mathrm{ng} / \mathrm{mL})$ of progesterone $(\mathrm{P} 4)$ from $2 \mathrm{~d}$ before the first GnRH (G1) treatment of the Ovsynch protocol to the last GnRH (G2) treatment. Cows had their estrous cycles synchronized using a Double-Ovsynch protocol. The first GnRH treatment of the Presynch portion of the Double-Ovsynch was followed by treatment with $\mathrm{PGF}_{2 \alpha} 7 \mathrm{~d}$ later and GnRH $72 \mathrm{~h}$ after $\mathrm{PGF}_{2 \alpha}$. Seven days later, cows received a GnRH (G1) treatment followed by $2 \mathrm{PGF}_{2}$ treatments administered 7 and 8 d later with the last GnRH (G2) treatment administered $56 \mathrm{~h}$ after the first $\mathrm{PGF}_{2 \alpha}$ treatment and $\mathrm{AI}$ 16 to $20 \mathrm{~h}$ later. Two days before G1 cows were blocked by parity (primiparous vs. multiparous) and were randomly assigned to serve as untreated controls (high-P4; - ) or to receive a half dose of $\mathrm{PGF}_{2 \alpha}$ (low-P4; $12.5 \mathrm{mg}$ dinoprost tromethamine; $\mathrm{O}$ ). Arrow denotes timing of treatment administration; points enclosed by the circle denote statistical analysis. Different letters (a to f) denote statistical differences $(P<0.05)$. Data are presented as means \pm SEM.
The percentage of cows diagnosed with twins $67 \mathrm{~d}$ after TAI did not differ $(P=0.31)$ between treatments $[5.4 \%(10 / 186)$ vs. $8.0 \%(16 / 200)$, for high-P4 vs. lowP4 cows, respectively); however, primiparous cows had fewer $(P=0.03)$ twin pregnancies than multiparous cows $[2.4 \%(3 / 125)$ vs. $8.8 \%(23 / 261)]$. Overall, the percentage of cows diagnosed with twins $67 \mathrm{~d}$ after TAI was $6.7 \%$.

\section{Progesterone Concentrations, CL Number and Volume, and CL Regression Between G1 and PGF $2 \alpha$}

Mean P4 concentration from $2 \mathrm{~d}$ before G1 to G2 was greater $(P<0.01)$ for high-P4 than for low-P4 cows. Two days before G1, mean P4 concentrations did not differ $(P=0.40)$ between treatments $(1.9$ vs. $1.7 \mathrm{ng} /$ $\mathrm{mL}$, for high-P4 vs. low-P4 cows, respectively; Figure $2)$. Nevertheless, mean P4 concentrations were greater $(P<0.01)$ for primiparous cows than for multiparous cows (2.1 vs. $1.7 \mathrm{ng} / \mathrm{mL}$, respectively). Furthermore, the distribution of cows based on $\mathrm{P} 4$ concentration $2 \mathrm{~d}$ before G1 did not differ between treatments (Figure 3, panel A).

At G1, mean P4 concentrations were greater $(P<$ 0.01 ) for high-P4 than for low-P4 cows (3.0 vs. $1.3 \mathrm{ng} /$ $\mathrm{mL}$, respectively; Figure 2). In addition, mean P4 concentrations were greater $(P<0.01)$ for primiparous cows than for multiparous cows $(2.3$ vs. $2.1 \mathrm{ng} / \mathrm{mL}$, respectively). When cows were divided into 9 categories based on P4 concentrations at G1 (Figure 3, panel B), more $(P<0.01)$ low-P4 cows had $\mathrm{P} 4$ concentrations $<1.5 \mathrm{ng} / \mathrm{mL}[62.8 \%(91 / 145)$ vs. $19.4 \%(28 / 144)$, respectively], whereas more $(P<0.01)$ high-P4 cows had $\mathrm{P} 4$ concentrations $\geq 2.5 \mathrm{ng} / \mathrm{mL}[56.9 \%(82 / 144)$ vs. $13.1 \%$ (19/145), respectively]. 


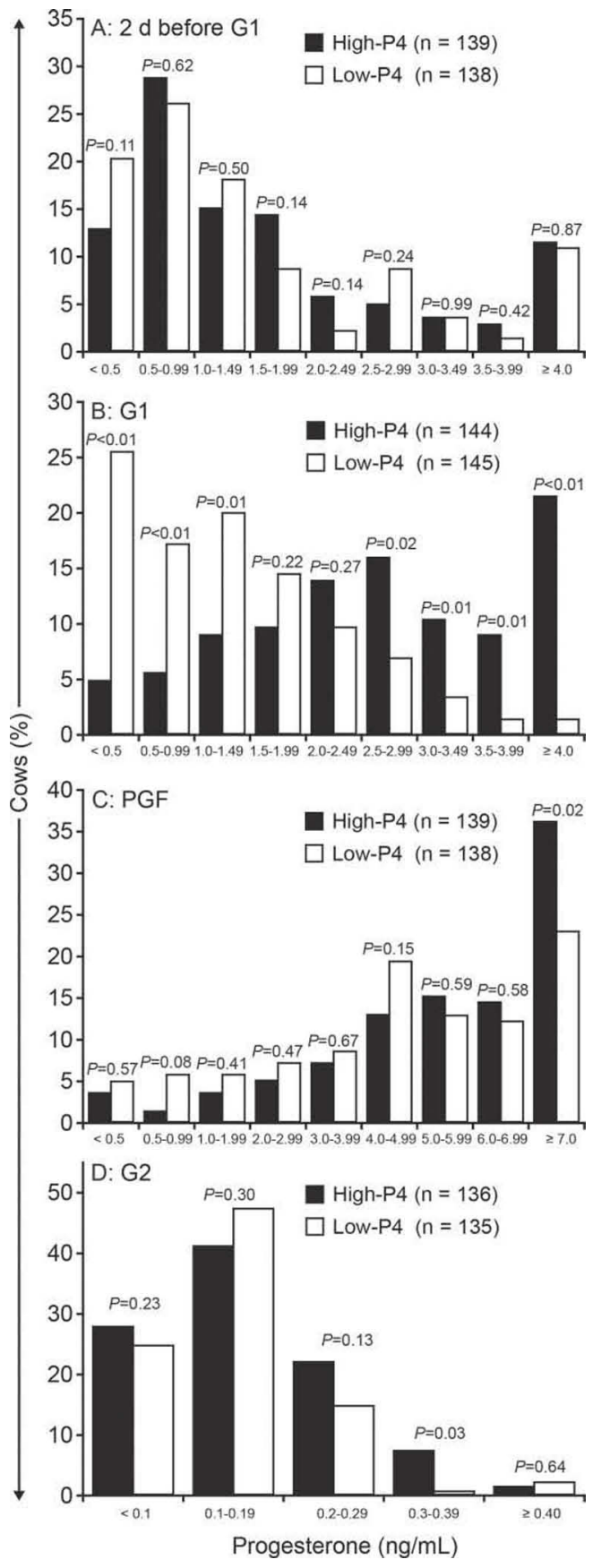

Figure 3. Distribution of cows based on progesterone (P4) concentrations at $2 \mathrm{~d}$ before the first GnRH (G1) treatment (panel A); at the first $\mathrm{GnRH}$ treatment (panel B); at the first $\mathrm{PGF}_{2 \alpha}$ treatment (panel $\mathrm{C}$ ); and at last GnRH treatment (panel D) of the Ovsynch protocol. Cows had their estrous cycles synchronized using a Double-Ovsynch protocol. The first GnRH treatment of the Presynch portion of the Double-Ovsynch was followed by treatment with $\mathrm{PGF}_{2 \alpha} 7 \mathrm{~d}$ later and GnRH $72 \mathrm{~h}$ after $\mathrm{PGF}_{2 \alpha}$. Seven days later, cows received a $\mathrm{GnRH}$ (G1) treatment followed by $2 \mathrm{PGF}_{2 \alpha}$ treatments administered 7 and $8 \mathrm{~d}$ later with the last GnRH (G2) treatment administered $56 \mathrm{~h}$ after the first $\mathrm{PGF}_{2 \alpha}$ treatment and $\mathrm{AI} 16$ to $20 \mathrm{~h}$ later. Two days before G1 cows were blocked by parity (primiparous vs. multiparous) and were randomly assigned to serve as untreated controls (high-P4; solid bars) or to receive a half dose of $\mathrm{PGF}_{2 \alpha}$ (low-P4; $12.5 \mathrm{mg}$ dinoprost tromethamine; open bars).
At the first $\mathrm{PGF}_{2 \alpha}$ treatment, mean $\mathrm{P} 4$ concentrations were greater $(P=0.04)$ for high-P4 cows than for low-P4 cows (6.2 vs. $5.1 \mathrm{ng} / \mathrm{mL}$, respectively, Figure $2)$. In addition, primiparous cows tended $(P=0.09)$ to have greater $\mathrm{P} 4$ concentrations than multiparous cows (6.1 vs. $5.5 \mathrm{ng} / \mathrm{mL}$, respectively). When cows were divided into 9 categories based on $\mathrm{P} 4$ concentrations at $\mathrm{PGF}_{2 \alpha}$, more high-P4 cows had extremely high $\mathrm{P} 4$ $(\geq 7.0 \mathrm{ng} / \mathrm{mL})$ concentrations (Figure 3, panel C).

At G2, mean P4 concentrations did not differ $(P=$ $0.33)$ between treatments $(0.16$ vs. $0.14 \mathrm{ng} / \mathrm{mL}$, for high-P4 vs. low-P4 cows, respectively; Figure 2); however, mean $\mathrm{P} 4$ concentrations were greater $(P=0.01)$ for primiparous cows than for multiparous cows $(0.17$ vs. 0.14, respectively). The distribution of cows based on P4 concentrations at G2 did not differ between treatments (Figure 3, panel D). Overall, only $1.8 \%$ $(5 / 271)$ of cows had $\mathrm{P} 4$ concentrations $\geq 0.4 \mathrm{ng} / \mathrm{mL}$ at G2 (Figure 3, panel D).

At G1, high-P4 cows had more $(P=0.02)$ CL compared with low-P4 cows (Table 2). In addition, luteal volume was greater $(P<0.01)$ for high-P4 compared with low-P4 cows (Table 2). Nevertheless, the proportion of cows with a CL at G1 did not differ $(P=0.97)$ between treatments (Table 2). The number of CL per cow did not differ $(P=0.57)$ between parities $(1.2 \pm$ 0.1 vs. $1.2 \pm 0.0$, for primiparous vs. multiparous cows, respectively). In addition, luteal volume did not differ $(P=0.63)$ between parities $\left(3,981\right.$ vs. $4,600 \mathrm{~mm}^{3}$, for primiparous vs. multiparous cows, respectively). The proportion of cows with a CL at G1 did not differ $(P$ $=0.97)$ between parities $[97.5 \%(39 / 40)$ vs. $96.3 \%$ (183/190), for primiparous vs. multiparous cows, respectively].

At the first $\mathrm{PGF}_{2 \alpha}$ treatment, the number of CL per cow did not differ $(P=0.57)$ between treatments (Table 2); however, luteal volume was greater $(P=$ 0.02 ) for high-P4 than for low-P4 cows (8,187 vs. 6,664 $\mathrm{mm}^{3}$, respectively). The number of CL per cow differed $(P=0.05)$ between parities $(1.6 \pm 0.1$ vs. $1.8 \pm 0.1$, for primiparous vs. multiparous cows, respectively) but luteal volume did not $\left(P=0.14 ; 6,811\right.$ vs. $7,754 \mathrm{~mm}^{3}$, for primiparous vs. multiparous cows, respectively). In addition, the proportion of cows with a CL did not differ $(P=0.99)$ between treatments (Table 2$)$ or parities $[P=0.99 ; 100.0 \%(35 / 35)$ vs. $99.4 \%(173 / 174)$, for primiparous vs. multiparous cows, respectively].

Premature regression of at least one CL between G1 and the first $\mathrm{PGF}_{2 \alpha}$ treatment occurred in $12.8 \%$ of cows $(26 / 203)$, and this response did not differ $(P=$ 0.34 ) between treatments (Table 2). Primiparous cows, however, had more $(P=0.05)$ CL regression from G1 to the first $\mathrm{PGF}_{2 \alpha}$ treatment than multiparous cows [23.5\% (8/34) vs. $10.7 \%$ (18/169), respectively]. 


\section{Ovulatory Follicle Size, Ovulatory Response at G1 and G2, and Double Ovulation at G2}

Follicle diameter at G1 did not differ $(P=0.80)$ between treatments (Table 2) or $(P=0.57)$ parities $(14.8 \pm 0.5 \mathrm{vs}, 14.8 \pm 0.2 \mathrm{~mm}$, for primiparous vs. multiparous cows, respectively). At G2, diameter of the ovulatory follicle did not differ $(P=0.20)$ between treatments (Table 2); however, primiparous cows had smaller $(P=0.04)$ ovulatory follicles than multiparous cows (14.9 vs. $15.9 \mathrm{~mm}$, respectively).

Almost all cows had a follicle $\geq 10 \mathrm{~mm}$ at G1 and did not differ $(P=0.99)$ between treatments (Table $2)$ or $(P=0.99)$ parities $[100.0 \%(40 / 40)$ vs. $98.9 \%$ $(188 / 190)$ for primiparous vs. multiparous cows, respectively]. Fewer $(P<0.01)$ high-P4 cows ovulated to G1 than low-P4 cows (Table 2). However, the ovulatory response to $\mathrm{G} 1$ did not differ $(P=0.77)$ between parities $[72 \%(28 / 39)$ vs. $70 \%(132 / 188)$ for primiparous vs. multiparous cows, respectively].

At G2, the ovulatory response was very high and did not differ $(P=0.99)$ between treatments (Table 2$)$ or $(P=0.99)$ parities $[97.1 \%(34 / 35)$ vs. $98.8 \%(162 / 164)$ for primiparous vs. multiparous cows, respectively]. The percentage of cows with double ovulation after G2 did not differ $(P=0.67)$ between treatments (Table 2$)$; however, primiparous cows tended to have fewer $(P=$ $0.10)$ double ovulations than multiparous cows $[11.4 \%$ $(4 / 35)$ vs. $24.4 \%$ (40/164), respectively].

\section{Effect of P4 Concentrations and Follicle Size on Ovulatory Response}

Ovulatory response (combined for both treatments) differed $(P<0.01)$ among $\mathrm{P} 4$ categories (Figure 4, left panel). Overall, cows with $\mathrm{P} 4$ concentrations $<1.5$ $\mathrm{ng} / \mathrm{mL}$ had greater $(P<0.01)$ ovulatory responses than cows with $\mathrm{P} 4$ concentrations $\geq 1.5 \mathrm{ng} / \mathrm{mL}[85.7 \%$ (84/98) vs. $58.9 \%$ (76/129), respectively; Figure 4, left panel].

In addition, an interaction $(P<0.01)$ between concentration of $\mathrm{P} 4(<1.5$ vs. $\geq 1.5 \mathrm{ng} / \mathrm{mL})$ at $\mathrm{G} 1$ and follicle size on ovulatory response was observed (Figure 4 , right panel). No cows $(\mathrm{n}=2)$ with follicles $<10 \mathrm{~mm}$ in diameter ovulated in response to G1. For cows with $\mathrm{P} 4 \geq 1.5 \mathrm{ng} / \mathrm{mL}$ at $\mathrm{G} 1$, ovulatory response increased as follicle size increased from 10 to $14 \mathrm{~mm}$ in diameter and then decreased as follicle diameter increased (Figure 4, right panel, solid symbols). For cows with $\mathrm{P} 4<1.5 \mathrm{ng} /$ $\mathrm{mL}$ at $\mathrm{G} 1$, ovulatory response increased as follicle size increased from 10 to $14 \mathrm{~mm}$ in diameter and remained

Table 2. Effect of treatment, on ovulatory response, follicle diameter at G1 and G2, proportion of cows with a follicle $\geq 10$ mm at G1, and proportion of cows with double ovulation to G2 of the Ovsynch protocol

\begin{tabular}{|c|c|c|c|}
\hline Item & \multicolumn{2}{|c|}{ Treatment $^{1}$} & $P$-value \\
\hline \multicolumn{4}{|l|}{ G1 } \\
\hline Follicle size, $\mathrm{mm}$ & $14.6 \pm 0.2$ & $15.0 \pm 0.3$ & 0.80 \\
\hline Cows with follicle $>10 \mathrm{~mm}, \%$ (no. $/$ no.) & $99.1(115 / 116)$ & $99.1(113 / 114)$ & 0.99 \\
\hline Cows with CL, \% (no./no.) & $98.3(114 / 116)$ & $94.7(108 / 114)$ & 0.97 \\
\hline \multicolumn{4}{|l|}{$\mathrm{PGF}_{2 \alpha}$} \\
\hline Cows with CL, \% (no./no.) & $100.0(105 / 105)$ & $99.0(103 / 104)$ & 0.99 \\
\hline CL per cow, no. & $1.8 \pm 0.1$ & $1.8 \pm 0.1$ & 0.57 \\
\hline CL volume, ${ }^{3} \mathrm{~mm}^{3}$ & $8,187 \pm 343$ & $6,664 \pm 318$ & 0.02 \\
\hline Cows regressing $\geq 1 \mathrm{CL}$ between $\mathrm{G} 1$ and $\mathrm{PGF}_{2 \alpha}, \%$ (no./no.) & $10.7(11 / 103)$ & $15.0(15 / 100)$ & 0.34 \\
\hline \multicolumn{4}{|l|}{$\mathrm{G} 2$} \\
\hline Ovulatory response, ${ }^{2} \%$ (no./no.) & $98.0(99 / 101)$ & $99.0(97 / 98)$ & 0.99 \\
\hline
\end{tabular}

${ }^{1}$ Cows had their estrous cycles synchronized for first timed AI using a Double-Ovsynch protocol. The first GnRH treatment of the Presynch portion of the Double-Ovsynch protocol was followed by treatment with $\mathrm{PGF}_{2 \alpha} 7 \mathrm{~d}$ later and GnRH $72 \mathrm{~h}$ after PGF $2 \alpha$. Seven days later, cows received a $\mathrm{GnRH}(\mathrm{G} 1)$ treatment followed by $2 \mathrm{PGF}_{2 \alpha}$ treatments administered 7 and 8 d later with the last GnRH (G2) treatment administered $56 \mathrm{~h}$ after the first $\mathrm{PGF}_{2 \alpha}$ treatment and timed $\mathrm{AI} 16$ to $20 \mathrm{~h}$ later. Two days before G1, cows were blocked by parity (primiparous vs. multiparous) and were randomly assigned to serve as untreated controls (high progesterone, $\mathrm{P} 4$ ) or to receive a half dose of PGF $2 \alpha$ (low $\mathrm{P} 4 ; 12.5$ $\mathrm{mg}$ of dinoprost tromethamine).

${ }^{2}$ Ovulation was defined based on disappearance of one or more ovulatory-sized follicles ( $\geq 10 \mathrm{~mm}$ in diameter) within $56 \mathrm{~h}$ after the GnRH treatment.

${ }^{3}$ Total corpus luteum (CL) volume was determined with the formula $\mathrm{V}=4 / 3 \times \pi \times \mathrm{R}^{3}$, using a radius (R) obtained with the formula $\mathrm{R}=$ (length $/ 2+$ width/2)/2. When a cavity was present, the volume of the cavity was calculated and subtracted from the total CL volume. 

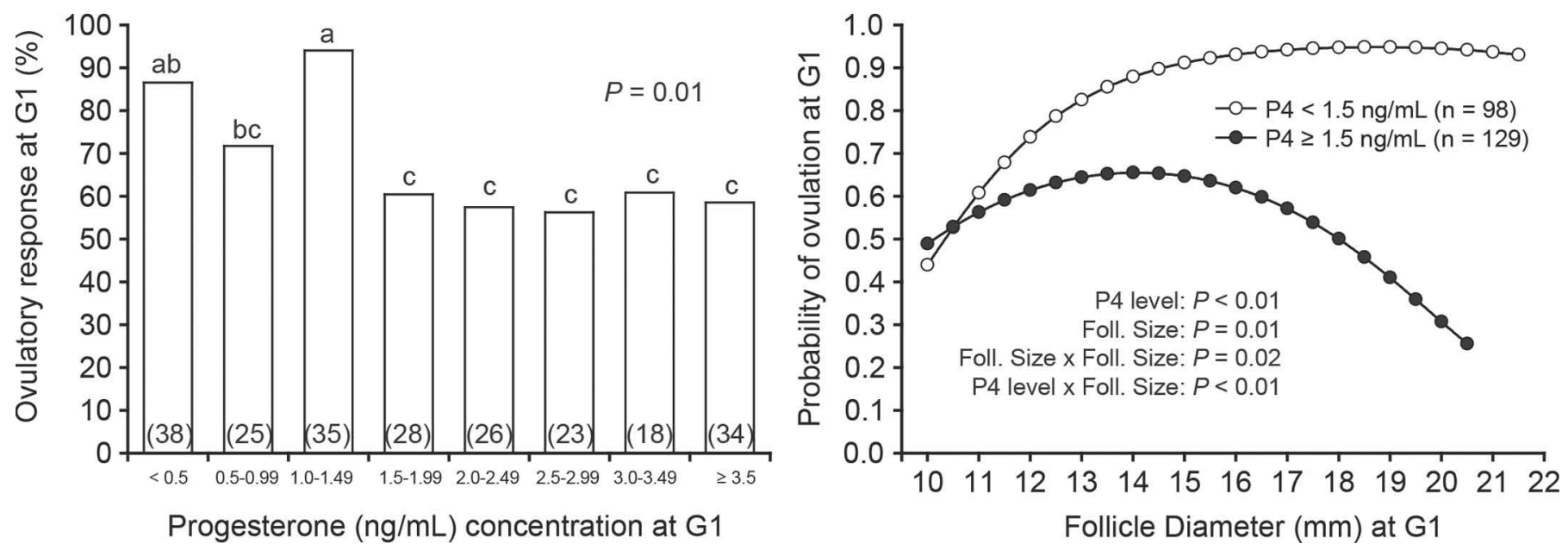

Figure 4. Effect of progesterone $(\mathrm{P} 4 ; \mathrm{ng} / \mathrm{mL})$ concentrations (left panel) and follicle size for cows with low $(<1.5 \mathrm{ng} / \mathrm{mL} ; \bigcirc)$ and high $(\geq 1.5$ $\mathrm{ng} / \mathrm{mL} ;-$ ) progesterone (right panel) at the at the first GnRH treatment (G1) of the Ovsynch protocol on ovulatory response. Ovulation was determined based on presence of a follicle (Folli) $\geq 10 \mathrm{~mm}$ in diameter at the GnRH treatment and disappearance of the structure by $56 \mathrm{~h}$ after the $\mathrm{GnRH}$ treatment. Numbers in parentheses denote the number of observations. Different letters $(\mathrm{a}-\mathrm{c})$ denote statistical differences at $P<0.05$.

high as follicle diameter increased (Figure 4, right panel, open symbols)

\section{Ovarian Characteristics, P4, and P/Al for Cows Ovulating or Not to G1}

Differences among various physiological measures between cows ovulating or not ovulating at G1 are summarized in Table 3. At G1, the proportion of cows with a follicle $\geq 10 \mathrm{~mm}$ tended $(P=0.08)$ to be greater for cows ovulating than for cows not ovulating to G1. Nevertheless, average follicle diameter $(P=0.16)$ and the proportion of cows with CL $(P=0.44)$ did not differ between cows ovulating and not ovulating to G1 (Table 3). Cows ovulating to G1, however, had lower $\mathrm{P} 4$ concentrations $(P<0.01)$ and a smaller proportion of cows with $\mathrm{P} 4>0.5 \mathrm{ng} / \mathrm{mL}(P=0.01)$ than cows not ovulating to G1 (Table 3). Cows ovulating to G1 also had fewer CL $(P<0.01)$ and less CL volume $(P<$ 0.01 ) than cows not ovulating to G1 (Table 3 ).

In contrast, at the $\mathrm{PGF}_{2 \alpha}$ treatment, cows that ovulated to $\mathrm{G} 1$ tended to have greater $(P=0.10) \mathrm{P} 4$ concentrations, a greater proportion of cows with $\mathrm{P} 4$ $\geq 1.0 \mathrm{ng} / \mathrm{mL}(P=0.03)$, and greater $\mathrm{CL}$ volume $(P=$ $0.03)$ than cows that did not ovulate to G1. However, the percentage of cows with a CL at PGF treatment did not differ $(P=0.27)$ between cows ovulating or not ovulating to G1 (Table 3).

Neither ovulatory response $(P=0.56)$ nor average follicle diameter $(P=0.21)$ at $\mathrm{G} 2$ differed between cows ovulating or not ovulating to G1 (Table 3). Furthermore, the proportion of cows with double ovulations at G2 did not differ $(P=0.60)$ between cows ovulating or not ovulating to G1 (Table 3). Progesterone concentrations at $\mathrm{G} 2$ did not differ $(P=0.12)$ between cows ovulating and not ovulating at G1 (Table 3 ). At $32 \mathrm{~d}$ after TAI, P/AI were greater $(P=0.03)$ for cows ovulating compared with cows not ovulating at G1 (Table 3).

\section{Effect of Follicle Diameter at G2 on P/Al for Cows Ovulating or Not to G1}

Cows were divided into 3 categories based on diameter of the ovulatory follicle at G2 $(<14,14$ to 18 , and $\geq 18 \mathrm{~mm}$ ). The distribution of cows based on diameter of the ovulatory follicle at G2 did not differ between cows ovulating or not ovulating to G1 (Figure 5, upper panel). Overall, 20.9\% (42/201), 65.2\% (131/201), and $13.9 \%(28 / 201)$ of the cows ovulated follicles of $<14.0$, 14.0 to 18.0 , and $\geq 18 \mathrm{~mm}$ (Figure 5 , upper panel). For cows with ovulatory follicles of $<14.0 \mathrm{~mm}$ in diameter, $\mathrm{P} / \mathrm{AI}$ did not differ $(P=0.90)$ between cows ovulating or not ovulating at G1 $556.0(14 / 25)$ vs. $53.8 \%(7 / 13)$, respectively; Figure 5, lower panel]; however, for cows with ovulatory follicles $\geq 14.0 \mathrm{~mm}$ in diameter, $\mathrm{P} / \mathrm{AI}$ were greater $(P<0.01)$ for cow ovulating compared with cows not ovulating to G1 $[61.6 \%(69 / 112)$ vs. $36.4 \%$ (16/44), respectively; Figure 5, lower panel].

\section{DISCUSSION}

A more complete understanding of the factors that affect fertility to timed AI protocols may lead to new and more effective strategies for improving reproduction in lactating dairy cows. The present study provides novel information on key physiological responses during 
a program for synchronization of ovulation that can improve $\mathrm{P} / \mathrm{AI}$. We tested the hypothesis that circulating P4 concentrations could be temporarily decreased at G1 by administering $12.5 \mathrm{mg}$ (i.e., a half-dose) of dinoprost tromethamine on $\mathrm{d} 5$ of a synchronized estrous cycle and that this manipulation would not result in complete luteal regression but would allow for greater ovulatory response to G1 2 d later.

The ability of the early CL to recover after administration of $\mathrm{PGF}_{2 \alpha}$ is remarkable. Because cows generally ovulate about $28 \mathrm{~h}$ after the final $\mathrm{GnRH}$ treatment of Ovsynch (Pursley et al., 1995), cows that were synchronized by the presynchronization Ovsynch protocol would be expected to have a CL that would be less than $4 \mathrm{~d}$ old at the time of the half-dose of $\mathrm{PGF}_{2 \alpha}$ treatment. A great deal of previous research indicates that this early CL should not undergo complete CL regression in response to a single $\mathrm{PGF}_{2 \alpha}$ treatment (Rowson et al., 1972; Henricks et al., 1974; Momont and Sequin, 1984) but recent research demonstrates the dramatic decrease in circulating $\mathrm{P} 4$ before recovery of the CL (Nascimento et al., 2014). The P4 profile that we observed (Figure 2) after administration of 12.5 $\mathrm{mg}$ of $\mathrm{PGF}_{2 \alpha}$ supports our hypothesis that the early $\mathrm{CL}$ does not regress in response to exogenous $\mathrm{PGF}_{2 \alpha}$ (Nascimento et al., 2014), particularly if a reduced dose of $\mathrm{PGF}_{2 \alpha}$ is utilized. The lack of regression of the early CL is an intriguing biological phenomenon that is not yet clearly understood; however, the inability to completely activate intracellular signal transduction pathways has been postulated and supported (Tsai and Wiltbank, 1998; Mondal et al., 2011; Diaz et al., 2013). In this study, we attempted to use this biological property in a practical way to increase ovulation at the start of Ovsynch while maintaining high P4 during the protocol. The increase in ovulation at G1 and the elevated $\mathrm{P} 4$ at $\mathrm{PGF}_{2 \alpha}$ in most cows indicate that this was successful. When Ovsynch is initiated at a random stage of the estrous cycle, about 10 to $15 \%$ of cows show premature luteal regression and ovulation, and these cows would have a somewhat older CL $(>5 \mathrm{~d})$ at the time of treatment with the half-dose of $\mathrm{PGF}_{2 \alpha}$. (Vasconcelos et al., 1999; Gumen et al., 2003). Therefore, we expected a small proportion of cows to undergo luteal regression before the final $\mathrm{PGF}_{2 \alpha}$ treatment of the Double-Ovsynch protocol. However, we observed a similar percentage of cows with premature CL regression $(\sim 13 \%)$ in cows treated or not treated with the half dose of $\mathrm{PGF}_{2 \alpha}$ indicating that this was not a large problem in this study.

The results of the present study also support the idea that presence of an ovulatory sized follicle $(\geq 10$ $\mathrm{mm}$ in diameter) does not guarantee an ovulation after treatment with GnRH (Bello et al., 2006; Galvão and

Table 3. Ovarian characteristics and progesterone (P4) concentration at G1 (first GnRH), PGF ${ }_{2 \alpha}$, G2 (second $\mathrm{GnRH})$ and pregnancies per $\mathrm{AI}(\mathrm{P} / \mathrm{AI})$ for cows ovulating or not to the G1 treatment of the Ovsynch protocol ${ }^{1}$

\begin{tabular}{|c|c|c|c|}
\hline \multirow[b]{2}{*}{ Item } & \multicolumn{2}{|c|}{ Ovulation at $\mathrm{G} 1^{2}$} & \multirow[b]{2}{*}{$P$-value } \\
\hline & No & Yes & \\
\hline \multicolumn{4}{|l|}{ G1 } \\
\hline Follicle size, $\mathrm{mm}$ & $14.4 \pm 0.4$ & $14.9 \pm 0.2$ & 0.16 \\
\hline Cows with follicle $\geq 10 \mathrm{~mm}, \%$ (no./no.) & $97.0(65 / 67)$ & $100.0(160 / 160)$ & 0.08 \\
\hline Progesterone, $\mathrm{ng} / \mathrm{mL}$ & $2.71 \pm 0.24$ & $1.87 \pm 0.14$ & $<0.01$ \\
\hline Cows with $\mathrm{P} 4>0.5 \mathrm{ng} / \mathrm{mL}, \%$ (no. $/$ no.) & $92.5(62 / 67)$ & $79.4(127 / 160)$ & 0.01 \\
\hline CL per cow, no. & $1.4 \pm 0.1$ & $1.1 \pm 0.1$ & $<0.01$ \\
\hline Cows with CL, \% (no./no.) & $98.5(66 / 67)$ & $95.6(153 / 160)$ & 0.44 \\
\hline CL volume, ${ }^{3} \mathrm{~mm}^{3}$ & $5,612 \pm 404$ & $4,047 \pm 226$ & $<0.01$ \\
\hline \multicolumn{4}{|l|}{$\mathrm{PGF}_{2 \alpha}$} \\
\hline Progesterone, ng/mL & $4.84 \pm 0.35$ & $5.56 \pm 0.24$ & 0.10 \\
\hline Cows with $\mathrm{P} 4>1 \mathrm{ng} / \mathrm{mL}, \%$ (no./no.) & $84.3(54 / 64)$ & $93.7(148 / 158)$ & 0.03 \\
\hline Cows with CL, \% (no./no.) & $98.3(57 / 58)$ & $100.0(151 / 151)$ & 0.27 \\
\hline CL volume,${ }^{3} \mathrm{~mm}^{3}$ & $6,573 \pm 382$ & $7,754 \pm 293$ & 0.03 \\
\hline \multicolumn{4}{|l|}{ G2 } \\
\hline Ovulatory response, ${ }^{2} \%$ (no./no.) & $100.0(57 / 57)$ & $97.9(139 / 142)$ & 0.56 \\
\hline Follicle size, mm & $15.4 \pm 0.3$ & $15.9 \pm 0.2$ & 0.21 \\
\hline Double ovulation, \% (no./no.) & $24.6(14 / 57)$ & $21.1(30 / 142)$ & 0.60 \\
\hline Progesterone, $\mathrm{ng} / \mathrm{mL}$ & $0.12 \pm 0.01$ & $0.14 \pm 0.01$ & 0.12 \\
\hline $\mathrm{P} / \mathrm{AI}$ at $32 \mathrm{~d}, \%$ (no./no.) & $41.8(28 / 67)$ & $58.2(89 / 153)$ & 0.03 \\
\hline
\end{tabular}



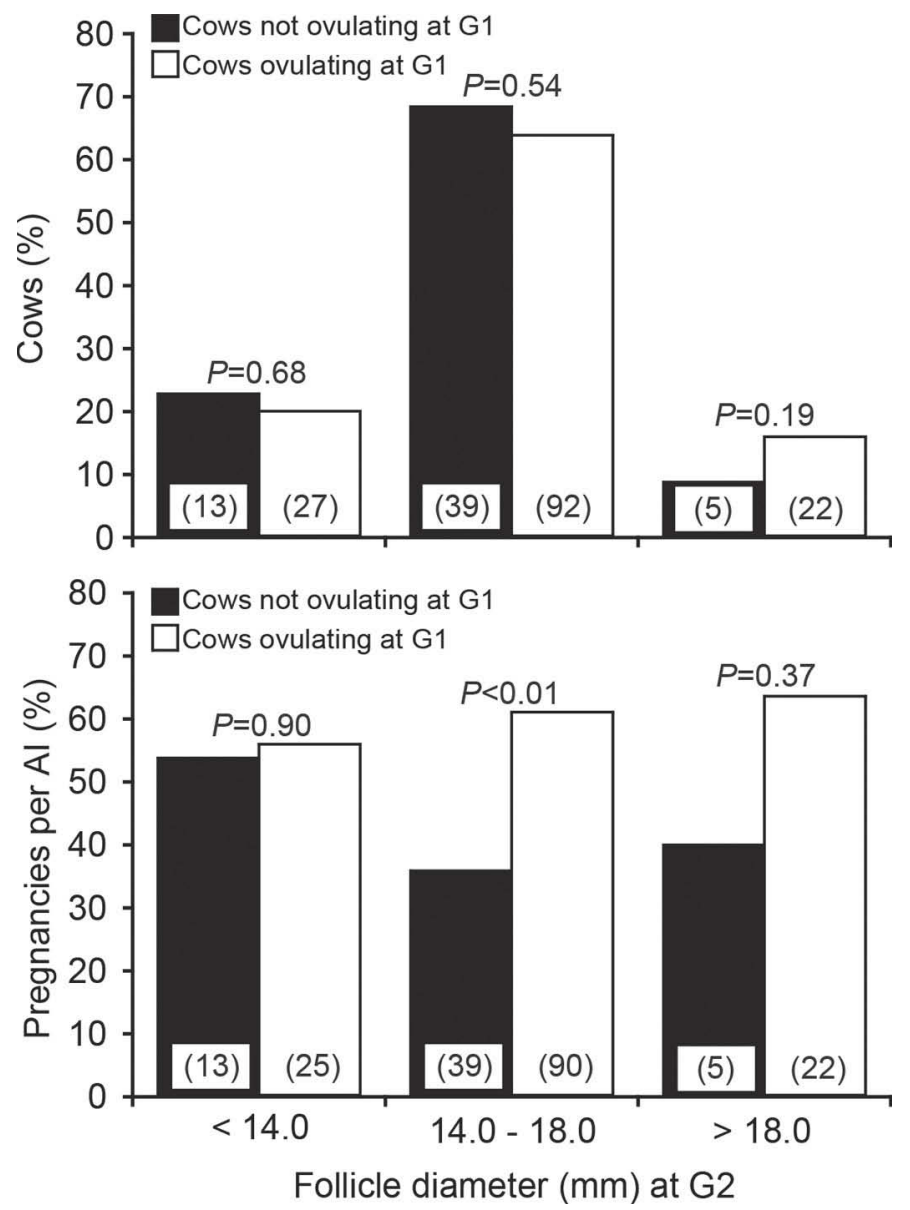

Figure 5. Distribution of cows (upper panel) and pregnancies per AI $32 \mathrm{~d}$ after timed AI (lower panel) based on follicle diameter at G2 for cows ovulating (white bars) and cows not ovulating (black bars) at G1 (upper panel). Cows had their estrous cycles synchronized using a Double-Ovsynch protocol. The first GnRH treatment of the Presynch portion of the Double-Ovsynch was followed by treatment with $\mathrm{PGF}_{2 \alpha} 7 \mathrm{~d}$ later and $\mathrm{GnRH} 72 \mathrm{~h}$ after $\mathrm{PGF}_{2 \alpha}$. Seven days later, cows were treated with GnRH (G1) followed by $2 \mathrm{PGF}_{2 \alpha}$ treatments administered 7 and $8 \mathrm{~d}$ later with the last $\mathrm{GnRH}$ (G2) treatment administered $56 \mathrm{~h}$ after the first $\mathrm{PGF}_{2 \alpha}$ treatment and AI 16 to $20 \mathrm{~h}$ later. Two days before G1 cows were blocked by parity (primiparous vs. multiparous) and were randomly assigned to serve as untreated controls (high-progesterone; $\mathrm{P} 4$ ) or to receive a half dose of $\mathrm{PGF}_{2}$ (low-P4; $12.5 \mathrm{mg}$ of dinoprost tromethamine). Ovulation was defined based on disappearance of one or more ovulatory-sized follicles $(\geq 10$ $\mathrm{mm}$ in diameter) within $56 \mathrm{~h}$ after the $\mathrm{GnRH}$ treatment. Numbers in parentheses denote the number of observations.

Santos, 2010; Giordano et al., 2013) because only $71 \%$ of follicles $\geq 10 \mathrm{~mm}$ in diameter ovulated in response to G1. In this regard, Sartori et al. (2001) evaluated ovulatory response in cows with follicles of approximately $10 \mathrm{~mm}$ in diameter and reported that $80 \%$ of cows ovulated after treatment with $40 \mathrm{mg}$ of $\mathrm{LH}$ compared with $69 \%$ and $8 \%$ ovulatory responses for cows treated with $24 \mathrm{mg}$ and $4 \mathrm{mg}$ of LH. Nevertheless, percentage of cows ovulating increased in response to $4 \mathrm{mg}$ of $\mathrm{LH}$ as follicles grew until $100 \%$ of follicles over $13 \mathrm{~mm}$ in diameter ovulated in response to the 4-mg dose of LH (Sartori et al., 2001). This result indicates that even though follicles have undergone selection by $10 \mathrm{~mm}$ diameter, LH responsiveness continues to increase as the follicle grows, probably due to increased expression of LH receptors (Luo et al., 2011). Thus, ovulation of the follicle at G1 likely involves an interaction between magnitude of the LH surge and LH responsiveness of the follicle. In agreement with the idea that a greater LH dose increases incidence of ovulation, increasing the dose of $\mathrm{GnRH}$ during a hormonal synchronization protocol increased the magnitude of the $\mathrm{GnRH}$-induced LH surge and the incidence of ovulation (Giordano et al., 2012a, 2013). In the present study, all cows received the same dose of $\mathrm{GnRH}(100 \mu \mathrm{g})$. Another factor affecting the magnitude of the GnRH-induced LH surge is the concentration of $\mathrm{P} 4$ at the time of GnRH treatment (Giordano et al., 2012a). For example, peak LH concentrations were almost 5 -fold greater (15.7 vs. 3.3 $\mathrm{ng} / \mathrm{mL}$ ) in cows treated with $100 \mu \mathrm{g}$ of $\mathrm{GnRH}$ in low $\mathrm{P} 4$ versus high P4 concentrations (Giordano et al., 2012a). Although LH concentrations were not measured in the present study, it is possible that the greater ovulatory response observed in cows with $\mathrm{P} 4<1.5 \mathrm{ng} / \mathrm{mL}$ at $\mathrm{G} 1$ was caused by a greater LH surge in response to G1. The exact mechanism of the negative effect of $\mathrm{P} 4$ on the GnRH-induced LH surge is not clearly understood. A decrease in number of $\mathrm{GnRH}$ receptors and a decrease in responsiveness of $\mathrm{GnRH}$ receptors to exogenous GnRH have been suggested as potential mechanisms (Rispoli and Nett, 2005; Giordano et al., 2012a). Nevertheless, the greater ovulatory response in cows with $\mathrm{P} 4<1.5$ $\mathrm{ng} / \mathrm{mL}$ at $\mathrm{G} 1$ could also be related to differences in $\mathrm{LH}$ receptors in granulosa cells of follicles. Acquisition of LH receptors in granulosa cells of follicles during follicular deviation is dependent upon LH, and treatment of cows with acyline ( $\mathrm{GnRH}$ antagonist) blocked an increase in LH receptors in granulosa cells of follicles during deviation (Luo et al., 2011). Furthermore, low $\mathrm{P} 4$ concentrations are associated with an increased LH pulse frequency (Kinder et al., 1996). Therefore, it is possible that the low $\mathrm{P} 4$ concentration in cows with $\mathrm{P} 4$ $<1.5 \mathrm{ng} / \mathrm{mL}$ increased LH pulse frequency, which in turn increased the expression of LH receptors in granulosa cells, thereby increasing ovulatory response after a GnRH-induced LH surge.

An intriguing finding in the present study was the interaction between level of $\mathrm{P} 4$ and follicle diameter at G1 on ovulatory response. In cows with higher P4, the ovulatory response decreased as follicles increased in size above $15 \mathrm{~mm}$ in diameter, whereas ovulatory response remained high even in larger follicles in cows with lower circulating P4 at G1. Again, this may be due 
to decreased magnitude of the LH surge in cows with higher P4 combined with a gradual loss of LH receptors as follicles grow beyond $15 \mathrm{~mm}$ in a high-P4 environment. In a similar scenario, the loss of $\mathrm{LH}$ responsiveness combined with reduced LH pulses is likely to underlie the reduction in growth rate and eventual atresia of the dominant follicle of the first follicular wave (Ginther et al., 1996). Studies are needed to evaluate whether the greater ovulatory response in cows with $\mathrm{P} 4<1.5 \mathrm{ng} /$ $\mathrm{mL}$ at $\mathrm{G1}$ is due to an increased $\mathrm{GnRH}$-induced $\mathrm{LH}$ surge, an increase in LH receptors in granulosa cells of follicles, or both, and to evaluate specific reasons for the decrease in ovulatory response of larger follicles in the presence of high $\mathrm{P} 4$ concentrations.

Many studies have consistently reported increased P/ AI for cows ovulating than for cows failing to ovulate to G1 (Chebel et al., 2006; Galvão et al., 2007; Giordano et al., 2013). The greater $\mathrm{P} / \mathrm{AI}$ in cows ovulating to G1 may be caused by greater synchronization rate in cows ovulating at G1 (Vasconcelos et al., 1999; Bello et al., 2006). Ovulation to G1 induces the formation of a CL, which will be present at the time of the $\mathrm{PGF}_{2 \alpha}$ treatment of the Ovsynch protocol, thereby increasing responses to the $\mathrm{PGF}_{2 \alpha}$ and $\mathrm{G} 2$ treatments of the protocol (Vasconcelos et al., 1999; Bello et al., 2006). Furthermore, cows with a CL or cows with high P4 $(\geq 1.0$ $\mathrm{ng} / \mathrm{mL}$ ) concentrations at $\mathrm{PGF}_{2 \alpha}$ treatment have more $\mathrm{P} / \mathrm{AI}$ than cows with no CL or cows with low P4 $(<1.0$ $\mathrm{ng} / \mathrm{mL}$ ) at this time (Giordano et al., 2012b; Carvalho et al., 2014a; Bisinotto et al., 2015). Interestingly, we did not observe a difference in the proportion of cows with a $\mathrm{CL}$ at the $\mathrm{PGF}_{2 \alpha}$ treatment based on ovulatory response to G1, but we did observe a decrease in the proportion of cows with $\mathrm{P} 4$ concentrations $<1.0 \mathrm{ng} /$ $\mathrm{mL}$ at the $\mathrm{PGF}_{2 \alpha}$ treatment for cows ovulating to G1. It might be expected that cows ovulating to G1 would have more d-7 CL at the time of the $\mathrm{PGF}_{2 \alpha}$ treatment, which may not completely regress in response to a single treatment with $\mathrm{PGF}_{2 \alpha}$. A decrease in $\mathrm{P} / \mathrm{AI}$ for cows with slightly increased $\mathrm{P} 4$ concentrations $(\geq 0.4$ or $0.5 \mathrm{ng} / \mathrm{mL}$ ) near AI has been reported (Souza et al., 2007; Brusveen et al., 2009; Lopes et al., 2013) and was the basis for the second $\mathrm{PGF}_{2 \alpha}$ treatment $24 \mathrm{~h}$ after the first in the synchronization protocol. Inclusion of the second $\mathrm{PGF}_{2 \alpha}$ treatment successfully induced complete luteal regression based on the observation that nearly all cows $(98.2 \%)$ had $\mathrm{P} 4$ concentration $<0.4 \mathrm{ng} / \mathrm{mL}$ at G2. Studies using a single $\mathrm{PGF}_{2 \alpha}$ treatment during a synchronization protocol have reported lower rates of luteal regression (70 to $88 \%$; Brusveen et al., 2009; Martins et al., 2011; Giordano et al., 2013).

Another interesting finding of the present study was the relationship between diameter of the ovulatory follicle at G2 and P/AI for cows ovulating or not ovulating to G1. Cows that did not ovulate at G1 had decreasing fertility with increasing size of the follicle at G2, although a similar relationship was not observed in cows that ovulated at G1 (Figure 5). Emergence of a new follicular wave occurs within $1 \mathrm{~d}$ after ovulation, which better controls the age and size of the ovulatory follicle at G2 (Wiltbank et al., 2011). Increased P/AI has been reported for cows ovulating follicles 14 to 18 $\mathrm{mm}$ in diameter compared with cows ovulating follicles $<14 \mathrm{~mm}$ or $>19 \mathrm{~mm}$ in diameter (Bello et al., 2006; Souza et al., 2007). Others have reported no decrease in $\mathrm{P} / \mathrm{AI}$ for cows ovulating follicles $>20 \mathrm{~mm}$ (Colazo et al., 2015). Ovulation of small follicles at G2 decreased estradiol concentration near AI, CL volume, and P4 concentration after $\mathrm{AI}$, and increased the incidence of short luteal phases after AI (Vasconcelos et al., 2001). We did not observe a decrease in $\mathrm{P} / \mathrm{AI}$ for cows ovulating follicles $<14.0 \mathrm{~mm}$ in diameter at G2 in the present study. Endometrial thickness increases after $\mathrm{PGF}_{2 \alpha}$ treatment, and slight increases in $\mathrm{P} 4$ concentrations at G2 are associated with decreased endometrial thickness (Souza et al., 2011). Cows with a thinner endometrium at G2 have fewer P/AI (Souza et al., 2011). We speculate that the rate of luteal regression achieved by adding a second $\mathrm{PGF}_{2 \alpha}$ treatment $24 \mathrm{~h}$ after the first may have better prepared the uterus for embryo implantation after AI by allowing for the estradiol produced by small follicles to act on the uterus to increase endometrial thickness and P/AI. In contrast, ovulation of larger follicles at G2 in cows failing to ovulate at G1 may be associated with ovulation of persistent or aged follicles, which may reduce embryo quality (Revah and Butler, 1996; Cerri et al., 2009) and P/AI (Mihm et al., 1994; Ahmad et al., 1996).

The data of $\mathrm{P} / \mathrm{AI}$ for cows ovulating or not ovulating at G1 also supports our hypothesis that increases in $\mathrm{P} / \mathrm{AI}$ for cows treated with a half-dose of $\mathrm{PGF}_{2 \alpha}$ are dependent on the increase in the proportion of cows ovulating to G1. The expected increase in P/AI based on increasing ovulatory response at G1 was 3.4 percentage points $(21 \%$ increase in ovulatory response at G1 $\times 16 \%$ increase in $\mathrm{P} / \mathrm{AI}$ for cows ovulating at G1). This expected increase exactly matched the treatment effect on $\mathrm{P} / \mathrm{AI}$ observed in the present study (Table 1). A larger sample size would be needed to detect a statistical difference of 3.4 percentage points between treatments. Although we did not compare the modified Double-Ovsynch protocol used in the present study with other synchronization protocols, it is worth noting the exceptional $\mathrm{P} / \mathrm{AI}$, which exceeded $50 \%$ in both primiparous and multiparous cows with high milk production inseminated at $\sim 80$ DIM for first service.

In conclusion, treatment of cows with $12.5 \mathrm{mg}$ of dinoprost tromethamine $2 \mathrm{~d}$ before G1 decreased P4 
concentrations (1.3 vs. $3.0 \mathrm{ng} / \mathrm{mL}$ ) without causing complete luteal regression and increased ovulatory response at G1 (80.1 vs. 60.3\%). Ovulatory response decreased when P4 concentrations at G1 exceeded 1.5 $\mathrm{ng} / \mathrm{mL}$. For cows with ovulatory follicles $<14.0 \mathrm{~mm}$ in diameter, $\mathrm{P} / \mathrm{AI}$ did not differ between cows ovulating or not ovulating to G1 (56.0 vs. $53.8 \%$, respectively); however, for cows with ovulatory follicles $\geq 14.0 \mathrm{~mm}$ in diameter, P/AI was greater for cows ovulating than for cows not ovulating to G1 (61.6 vs. $36.4 \%$, respectively).

\section{ACKNOWLEDGMENTS}

We thank the University of Wisconsin-Madison dairy herd personnel at the Blaine Dairy Cattle Center (Arlington, WI) for their assistance with data collection and cow handling during the course of this experiment, and the owners and herd personnel of Sunburst Dairy (Belleville, WI) for allowing us access to their cows and facilities to conduct this research. Our gratitude is also extended to Zoetis (Madison, NJ) for the donation of Lutalyse. This work was supported by the USDA National Institute of Food and Agriculture (Washington, DC) Hatch project 231440 to P. M. Fricke.

\section{REFERENCES}

Ahmad, N., R. A. Milvae, S. W. Beam, W. R. Butler, D. R. Deaver, R. T. Duby, D. R. Elder, J. E. Fortune, L. C. J. Griel, L. S. Jones, R. A. Milvae, J. L. Pate, I. Revah, D. T. Schreiber, D. H. Townson, P. C. W. Tsang, and E. K. I. Inskeep. 1996. Relationship of fertility to patterns of ovarian follicular development and associated hormonal profiles in dairy cows and heifers. J. Anim. Sci. 74:1943-1952.

Ayres, H., R. M. Ferreira, A. P. Cunha, R. R. Araujo, and M. C. Wiltbank. 2013. Double-Ovsynch in high-producing dairy cows: Effects on progesterone concentrations and ovulation to $\mathrm{GnRH}$ treatments. Theriogenology 79:159-164.

Bello, N. M., J. P. Steibel, and J. R. Pursley. 2006. Optimizing ovulation to first $\mathrm{GnRH}$ improved outcomes to each hormonal injection of Ovsynch in lactating dairy cows. J. Dairy Sci. 89:3413-3424.

Bisinotto, R. S., L. O. Castro, M. B. Pansani, C. D. Narciso, N. Martinez, L. D. P. Sinedino, T. L. C. Pinto, N. S. Van de Burgwal, H. M. Bosman, R. S. Surjus, W. W. Thatcher, and J. E. P. Santos. 2015. Progesterone supplementation to lactating dairy cows without a corpus luteum at initiation of the Ovsynch protocol. J. Dairy Sci. 98:2515-2528.

Brusveen, D. J., A. H. Souza, and M. C. Wiltbank. 2009. Effects of additional prostaglandin F $2 \alpha$ and estradiol-17 $\beta$ during Ovsynch in lactating dairy cows. J. Dairy Sci. 92:1412-1422.

Carvalho, P. D., J. N. Guenther, M. J. Fuenzalida, M. C. Amundson, M. C. Wiltbank, and P. M. Fricke. 2014a. Presynchronization using a modified Ovsynch protocol or a single gonadotropin-releasing hormone injection $7 \mathrm{~d}$ before an Ovsynch-56 protocol for submission of lactating dairy cows to first timed artificial insemination. J. Dairy Sci. 97:6305-6315.

Carvalho, P. D., A. H. Souza, M. C. Amundson, K. S. Hackbart, M. J. Fuenzalida, M. M. Herlihy, H. Ayres, A. R. Dresch, L. M. Vieira, J. N. Guenther, R. R. Grummer, P. M. Fricke, R. D. Shaver, and M. C. Wiltbank. 2014b. Relationships between fertility and postpartum changes in body condition and body weight in lactating dairy cows. J. Dairy Sci. 97:3666-3683.
Cerri, R. L. A., H. M. Rutigliano, R. C. Chebel, and J. E. P. Santos. 2009. Period of dominance of the ovulatory follicle influences embryo quality in lactating dairy cows. Reproduction 137:813-823.

Chebel, R. C., J. E. P. Santos, R. L. A. Cerri, H. M. Rutigliano, and R. G. S. Bruno. 2006. Reproduction in dairy cows following progesterone insert presynchronization and resynchronization protocols. J. Dairy Sci. 89:4205-4219.

Colazo, M. G., A. Behrouzi, D. J. Ambrose, and R. J. Mapletoft. 2015. Diameter of the ovulatory follicle at timed artificial insemination as a predictor of pregnancy status in lactating dairy cows subjected to GnRH-based protocols. Theriogenology 84:377-383.

Diaz, F. J., W. Luo, and M. C. Wiltbank. 2013. Prostaglandin F2alpha regulation of mRNA for activating protein 1 transcriptional factors in porcine corpora lutea (CL): Lack of induction of JUN and JUND in CL without luteolytic capacity. Domest. Anim. Endocrinol. 44:98-108.

Edmonson, A. J., I. J. Lean, L. D. Weaver, T. Farver, and G. Webster. 1989. A body condition scoring chart for Holstein dairy cows. J. Dairy Sci. 72:68-78.

Fricke, P. M., J. O. Giordano, A. Valenza, G. Lopes Jr., M. C. Amundson, and P. D. Carvalho. 2014. Reproductive performance of lactating dairy cows managed for first service using timed artificial insemination with or without detection of estrus using an activitymonitoring system. J. Dairy Sci. 97:2771-2781.

Galvão, K. N., M. F. Sá Filho, and J. E. P. Santos. 2007. Reducing the interval from presynchronization to initiation of timed artificial insemination improves fertility in dairy cows. J. Dairy Sci. 90:4212-4218

Galvão, K. N., and J. E. P. Santos. 2010. Factors affecting synchronization and conception rate after the Ovsynch protocol in lactating Holstein cows. Reprod. Domest. Anim. 45:439-446.

Ginther, O. J., M. C. Wiltbank, P. M. Fricke, J. R. Gibbons, and K. Kot. 1996. Selection of the dominant follicle in cattle. Biol. Reprod. 55:1187-1194.

Giordano, J. O., P. M. Fricke, J. N. Guenther, G. Lopes Jr., M. M. Herlihy, A. B. Nascimento, and M. C. Wiltbank. 2012a. Effect of progesterone on magnitude of the luteinizing hormone surge induced by two different doses of gonadotropin-releasing hormone in lactating dairy cows. J. Dairy Sci. 95:3781-3793.

Giordano, J. O., M. C. Wiltbank, P. M. Fricke, S. Bas, R. Pawlisch, J. N. Guenther, and A. B. Nascimento. 2013. Effect of increasing GnRH and PGF2 $\alpha$ dose during Double-Ovsynch on ovulatory response, luteal regression, and fertility of lactating dairy cows. Theriogenology 80:773-783.

Giordano, J. O., M. C. Wiltbank, J. N. Guenther, R. Pawlisch, S. Bas, A. P. Cunha, and P. M. Fricke. 2012b. Increased fertility in lactating dairy cows resynchronized with Double-Ovsynch compared with Ovsynch initiated $32 \mathrm{~d}$ after timed artificial insemination. J. Dairy Sci. 95:639-653.

Gümen, A., J. N. Guenther, and M. C. Wiltbank. 2003. Follicular size and response to Ovsynch versus detection of estrus in anovular and ovular lactating dairy cows. J. Dairy Sci. 86:3184-3194.

Henricks, D. M., J. T. Long, J. R. Hill, and J. F. Dickey. 1974. Effect of prostaglandin F2-alpha during various stages of estrous cycle of beef heifers. J. Reprod. Fertil. 41:113-120.

Herlihy, M. M., J. O. Giordano, A. H. Souza, H. Ayres, R. M. Ferreira, A. Keskin, A. B. Nascimento, J. N. Guenther, J. M. Gaska S. J. Kacuba, M. A. Crowe, S. T. Butler, and M. C. Wiltbank. 2012. Presynchronization with Double-Ovsynch improves fertility at first postpartum artificial insemination in lactating dairy cows. J. Dairy Sci. 95:7003-7014.

Kinder, J. E., F. N. Kojima, E. G. Bergfeld, M. E. Wehrman, and K. E. Fike. 1996. Progestin and estrogen regulation of pulsatile LH release and development of persistent ovarian follicles in cattle. J. Anim. Sci. 74:1424-1440.

Lopes, G., Jr., J. O. Giordano, A. Valenza, M. M. Herlihy, J. N. Guenther, M. C. Wiltbank, and P. M. Fricke. 2013. Effect of timing of initiation of resynchronization and presynchronization with gonadotropin-releasing hormone on fertility of resynchronized inseminations in lactating dairy cows. J. Dairy Sci. 96:3788-3798. 
Luo, W., A. Gumen, J. M. Haughian, and M. C. Wiltbank. 2011. The role of luteinizing hormone in regulating gene expression during selection of a dominant follicle in cattle. Biol. Reprod. 84:369-378.

Martins, J. P. N., R. K. Policelli, L. M. Neuder, W. Raphael, and J. R. Pursley. 2011. Effects of cloprostenol sodium at final prostaglandin $\mathrm{F}_{2 \alpha}$ of Ovsynch on complete luteolysis and pregnancy per artificial insemination in lactating dairy cows. J. Dairy Sci. 94:2815-2824.

Mihm, M., A. Baguisi, M. P. Boland, and J. F. Roche. 1994. Association between the duration of dominance of the ovulatory follicle and pregnancy rate in beef heifers. J. Reprod. Fertil. 102:123-130.

Momont, H. W., and B. E. Sequin. 1984. Influence of day of estrous cycle on response to PGF2 alpha products: Implication for AI programs for dairy cattle. Pages 336-338 in 10th International Congress on Animal Reproduction and Artificial Insemination. Vol. III. University of Illinois at Urbana-Champaign, IL.

Mondal, M., B. Schilling, J. Folger, J. P. Steibel, H. Buchnick, Y. Zalman, J. J. Ireland, R. Meidan, and G. W. Smith. 2011. Deciphering the luteal transcriptome: potential mechanisms mediating stage-specific luteolytic response of the corpus luteum to prostaglandin F-2 alpha. Physiol. Genomics 43:447-456.

Moreira, F., C. Orlandi, C. A. Risco, R. Mattos, F. Lopes, and W. W. Thatcher. 2001. Effects of presynchronization and bovine somatotropin on pregnancy rates to a timed artificial insemination protocol in lactating dairy cows. J. Dairy Sci. 84:1646-1659.

Nascimento, A. B., A. H. Souza, A. Keskin, R. Sartori, and M. C. Wiltbank. 2014. Lack of complete regression of the Day 5 corpus luteum after one or two doses of $\mathrm{PGF}_{2 \alpha}$ in nonlactating Holstein cows. Theriogenology 81:389-395.

Navanukraw, C., D. A. Redmer, L. P. Reynolds, J. D. Kirsch, A. T. Grazul-Bilska, and P. M. Fricke. 2004. A modified presynchronization protocol improves fertility to timed artificial insemination in lactating dairy cows. J. Dairy Sci. 87:1551-1557.

NRC. 2001. Nutrient Requirements of Dairy Cattle. 7th rev. ed. The National Academies Press, Washington, DC.

Pursley, J. R., M. R. Kosorok, and M. C. Wiltbank. 1997. Reproductive management of lactating dairy cows using synchronization of ovulation. J. Dairy Sci. 80:301-306.

Pursley, J. R., M. O. Mee, and M. C. Wiltbank. 1995. Synchronization of ovulation in dairy cows using PGF2 $\alpha$ and GnRH. Theriogenology 44:915-923.

Revah, I., and W. R. Butler. 1996. Prolonged dominance of follicles and reduced viability of bovine oocytes. J. Reprod. Fertil. 106:3947.
Rispoli, L. A., and T. M. Nett. 2005. Pituitary gonadotropin-releasing hormone $(\mathrm{GnRH})$ receptor: Structure, distribution and regulation of expression. Anim. Reprod. Sci. 88:57-74.

Rowson, L. E., R. Tervit, and A. Brand. 1972. The use of prostaglandins for synchronization of oestrus in cattle. J. Reprod. Fertil. 29:145.

Sartori, R., P. M. Fricke, J. C. P. Ferreira, O. J. Ginther, and M. C. Wiltbank. 2001. Follicular deviation and acquisition of ovulatory capacity in bovine follicles. Biol. Reprod. 65:1403-1409.

Souza, A. H., H. Ayres, R. M. Ferreira, and M. C. Wiltbank. 2008. A new presynchronization system (Double-Ovsynch) increases fertility at first postpartum timed AI in lactating dairy cows. Theriogenology 70:208-215.

Souza, A. H., A. Gümen, E. P. B. Silva, A. P. Cunha, J. N. Guenther, C. M. Peto, D. Z. Caraviello, and M. C. Wiltbank. 2007. Supplementation with estradiol-17 $\beta$ before the last gonadotropinreleasing hormone injection of the Ovsynch protocol in lactating dairy cows. J. Dairy Sci. 90:4623-4634.

Souza, A. H., E. P. B. Silva, A. P. Cunha, A. Gümen, H. Ayres, D. J. Brusveen, J. N. Guenther, and M. C. Wiltbank. 2011. Ultrasonographic evaluation of endometrial thickness near timed AI as a predictor of fertility in high-producing dairy cows. Theriogenology 75:722-733.

Tsai, S. J., and M. C. Wiltbank. 1998. Prostaglandin F2alpha regulates distinct physiological changes in early and mid-cycle bovine corpora lutea. Biol. Reprod. 58:346-352.

Vasconcelos, J. L. M., R. Sartori, H. N. Oliveira, J. G. Guenther, and M. C. Wiltbank. 2001. Reduction in size of the ovulatory follicle reduces subsequent luteal size and pregnancy rate. Theriogenology $56: 307-314$

Vasconcelos, J. L. M., R. W. Silcox, G. J. M. Rosa, J. R. Pursley, and M. C. Wiltbank. 1999. Synchronization rate, size of the ovulatory follicle, and pregnancy rate after synchronization of ovulation beginning on different days of the estrous cycle in lactating dairy cows. Theriogenology 52:1067-1078.

Wiltbank, M. C., and J. R. Pursley. 2014. The cow as an induced ovulator: Timed AI after synchronization of ovulation. Theriogenology 81:170-185.

Wiltbank, M. C., R. Sartori, M. M. Herlihy, J. L. M. Vasconcelos, A. B. Nascimento, A. H. Souza, H. Ayres, A. P. Cunha, A. Keskin. J. N. Guenther, and A. Gumen. 2011. Managing the dominant follicle in lactating dairy cows. Theriogenology 76:1568-1582 